Creating the Constitution 


\section{Thornton Anderson}

Creating the 
Constitution

The

Convention of 1787

and the

First Congress

The Pennsylvania State University Press

University Park, Pennsylvania 
Library of Congress Cataloging-in-Publication Data

Anderson, Thornton, 1915-

Creating the Constitution : the Convention of 1787 and the first Congress

/ Thornton Anderson.

p. $\quad \mathrm{cm}$.

Includes bibliographical references and index.

ISBN 978-0-2710-0920-9

1. United States-Constitutional history. 2. Federal government -United States-History. 3. United States-Politics and government-1783-1809. 4. Constitutional conventions-United States-History. 5. United States. Constitutional Convention (1787) 6. United States. Congress (1st: 1789-1791) I. Title. KF4541.A88 1993 342.73 '0292-dc20 [347.302292]

Copyright $\odot 1993$ The Pennsylvania State University All rights reserved Printed in the United States of America

Published by The Pennsylvania State University Press, Suite C, Barbara Building, University Park, PA 16802-1003

It is the policy of The Pennsylvania State University Press to use acid-free paper for the first printing of all clothbound books. Publications on uncoated stock satisfy the minimum requirements of American National Standard for Information SciencesPermanence of Paper for Printed Library Materials, ANSI Z39.48-1984. 
For my parents

Keturah Hogan Anderson

Thornton Hatfield Anderson who taught me independence 
This page intentionally left blank. 